\title{
The Anatomy of North Dakota State University Civil Engineering Capstone Design Course
}

\author{
Francis Peloubet (e-mail: Frank.Peloubet@ndsu.edu) \\ Eakalak Khan (e-mail: Eakalak.Khan@ndsu.edu) \\ G. Padmanabhan (e-mail: G.Padmanabhan@ndsu.edu) \\ Department of Civil Engineering \\ North Dakota State University \\ Fargo, ND 58108-6050
}

\begin{abstract}
The capstone design course offered by the Civil Engineering Department at North Dakota State University takes our graduating seniors outside of their normal comfort zone in a structured and supportive class environment. The course has steadily evolved to keep pace with the everchanging science and technology and the evolving expectations of the profession and the society we serve. In this model, carefully chosen real world projects are assigned. Faculty and guest speakers make presentations on engineering design process; engineering project management; leadership in an engineering environment; relationship of engineering projects, business, and public policy; global perspective in engineering; and professional career and licensure. Students work together in teams while a select number of faculties act as technical consultants. Other faculty members act as mentors for each student team to provide non-technical guidance and direction. Students are challenged through a project discovery phase to locate much information required to complete the design. The course requires students to demonstrate mastery of the curriculum and to work with others in a team environment. Course assessment include evaluation of two oral presentations, development of a project design schedule, a project design journal, 2-3 page reaction papers on five presentation topics, and three written technical reports.
\end{abstract}

\section{Background and Evolution}

Increased emphasis on design courses by the Accreditation Board for Engineering and Technology (ABET) caused many engineering schools to reevaluate the design component of their curricula in the late 1980s. The ABET has been particularly raising concerns about the fragmented approach to increase the total design content in the curricula. The ABET emphasized at least one course which is primarily design-oriented, preferably at the senior level, and integrated on the accumulated background of the curricular components be included in the curriculum. To make the transition from narrow-focus design offered in individual courses to the overall total civil engineering design experience, the Civil Engineering Department at North Dakota State University (NDSU), Fargo, North Dakota, established a capstone design course in the year $1990^{1,2}$. This course has successfully evolved over the years to the present status.

\section{0-92}

NDSU was operating in the quarter system until 1992. The capstone course was offered in the first two years since its inception as a 2-quarter, 3-credit course in the senior year. In the first quarter, students worked on preparing a proposal and presenting it. In the second quarter 
students carried out the design and presented their final product. Andersen ${ }^{1}$ reported the details and experience with this course two years after it was established. In this course, a design project was carefully selected to encompass many of the areas within civil engineering as well as other socioeconomic issues. Definition of the project was purposely left as open-ended as possible to encourage the students' imagination and ingenuity. Each faculty member acted as the adviser for one design group as well as the technical consultant in his/her area of expertise to all groups. Students had to consider the social, economic, and environmental factors associated with the project. In general, the students gained an appreciation for assigning specific individual duties within each group and working together toward a common goal. The course fulfilled the ABET criterion of a "combined background of curricular components." One of the recommendations for improvement was to bring in input by additional professionals from the engineering community at the beginning of the course that would give more of a real-world atmosphere to the project. These individuals could also be used to critique the designs at the final presentations. The presence of outside professionals would impress on the students the importance of the capstone design project. Example projects assigned in this period included design of an interstate highway rest area/information center and the design of a small regional airport. Actual field sites were selected for these projects ${ }^{1}$.

\section{$1992-96$}

NDSU switched to semester system in the year 1992. The capstone design course was converted to a 1-semester 2-credit course. At this time, firm goals were established for future offering of the course based on discussions by the faculty ${ }^{2}$.

1. To provide an open-ended design experience encompassing the major subject areas of civil engineering;

2. To allow students to address various socio-economic, environmental, and political issues of an engineering project;

3. To provide students an opportunity to function as a team in organizing and carrying out the design of an engineering project; and

4. To provide students an opportunity to develop oral and written communication skills.

Efforts continued to bring more real-world projects into the course. Initially, artificial elements were added to the projects selected for the course to include all aspects of civil engineering. Contour maps, soils data, traffic counts, water table data were made available for the selected sites. From 1992-1996, some of the projects were borrowed from the undergraduate theses completed by the NDSU Architecture department. This provided an opportunity for the students to interact with and interpret the architect's design. Projects assigned during this period included; a horse-race course, a senior high school, a golf course club house, a lake resort, and a community center. During this period, the process of group assignment was improved to ensure equitable distribution of responsibilities among the members. Students were asked to submit an organizational chart indicating who is responsible for what in the group. Each member in the group was expected to participate in the preliminary and final presentations. Each student was also required to prepare at least one of the final drawings. With only one semester available the groups had to immediately begin collecting data and examining the alternatives for their design. 
Usage of CAD drawings, word-processors and PowerPoint software were required for preparing reports and presentations ${ }^{2}$.

\section{6-2002}

In this period, two more goals were added to the already developed goals of the course since its inception:

1. To provide students with an opportunity to interact with the community and seek their feedback; and

2. To provide an opportunity to develop life-long learning habits and skills to relate seemingly unrelated ideas and integrate them in the overall design.

The Civil Engineering Department started using community-based projects in the capstone course to emphasize the importance of community integration in the civil engineering profession. Real-life projects for the course are carefully selected from the community. Faculty members expend considerable time in seeking suitable community-based projects for the course. Examples include: a water treatment plant component; a river marina; an interstate highway ramp; and slope stability problems. These projects had close cooperation from the community and the consulting engineers. Their input was used for defining the project and providing the students with the necessary information. Also, students were asked to present results to the faculty, community, and consultants. The feedback from clients during and after the question-answer sessions provided a valuable learning opportunity for students ${ }^{3}$.

\section{2-present}

Several changes have been made in the content, structure, operation, and assessment of the course. The importance of community-relevance of the projects has been recognized and is increasingly brought to bear on the course in recent years. The course has successfully kept pace with the ABET requirements for changes in assessment procedures over the years to move from teaching-centered to learning-centered and outcome-based strategy. Requirements have moved from requiring and grading only the final reports in the past to requiring and grading preliminary reports, presentations, reaction papers, etc. Use of instructional technology beginning from the use of Power Point presentations to AutoCAD to Blackboard teaching platform have been adopted promptly as the course evolved.

The course, as evolved to the present status, is discussed in the remaining sections of this paper.

\section{Course Goals and Objectives}

The course combines all aspects of the preparation, planning, design, and pre-construction phases of an engineering project into a single comprehensive and meaningful educational capstone experience that integrate engineering and management disciplines and reflect realworld engineering design practices. Students, working in small groups, use the knowledge and skills acquired throughout their undergraduate education to develop the documentation required for actual engineering project design (i.e. project analysis, design calculations, drawings, 
material quantities, basic cost estimate, design schedule, and an overall work plan) and present results in verbal, written, and electronic formats. Specific course goals are to:

- Prepare students for a professional civil engineering career;

- Demonstrate student's mastery of civil engineering curriculum;

- Provide 'Real World' experience in a controlled environment; and

- Ensure that the program provides student's the civil engineering education required to be successful in the working world.

\section{Course objectives include the ability to:}

- Successfully complete the discovery phase of an assigned civil engineering design project and utilize the acquired project data, plans, references, tools, techniques, and other resources accurately and effectively;

- Demonstrate and apply knowledge obtained from undergraduate curriculum courses;

- Work successfully in design teams to complete a complex multidisciplinary design project that meets desired needs and develops leadership skills;

- Prepare and present project design results as formal technical written and electronically submitted project reports and oral presentations using visual and graphical information;

- Utilize knowledge and skills to enter the engineering profession, understand ethical responsibilities in a societal context, and engage in continual/life-long learning; and

- Understanding how and why 'real-world' engineering projects impact or are impacted by contemporary issues and public policies in a global and societal context.

\section{Course Structure and Dynamics}

The NDSU Civil Engineering (CE) Department capstone experience is structured for students to work on an assigned design project within an educational environment that simulates working for a civil engineering design firm. This environment offers the graduating senior students an opportunity to demonstrate their knowledge and proficiency gained from the CE program curriculum. Engineering design firms, agencies, alumni, and organizations in the area work with the CE Department to suggest and/or sponsor an existing or proposed 'real world' civil engineering project. After discussing a proposed design project with the project sponsor it is reviewed by the Department Chairperson, faculty, and the assigned capstone facilitator/coordinator. Once the design project is approved, all relevant and necessary project documents are identified and assembled. This process is endorsed and supported by the CE Department Industry Advisory Committee and the CE Department.

One faculty member acts as a facilitator and coordinator for the capstone experience course. The course facilitator's responsibilities include: CE Department meetings to select, review, and scope the design project; maintaining the course NDSU Blackboard web site; course documentation; project documentation; formation of five-member student design teams; ensuring student awareness of course requirements and schedule; several class lectures; scheduling ABET topic guest speakers; scheduling faculty class presentations; coordinating faculty scoring of assessment tools; scoring ABET topic reaction papers; scheduling student design team 
presentations; recording and posting all student assessment scores; and calculation and posting of final course grades.

Five faculty members are assigned to the capstone project to represent the environmental, geotechnical, structural, transportation, and water resources five areas of the civil engineering discipline. They act as both technical consultants that simulate principle engineers of the firm and clients that simulate the project owners who hired the firm. These five faculty members scope the project to ensure a manageable level and volume of design work for the students. Each faculty member presents design project information and requirements for their specific civil engineering areas to the capstone class. They also prepare technical report writing requirements for their respective areas and post the information on the course NDSU Blackboard web site.

Since the NDSU CE curriculum includes the five basic CE technical areas, five-member student design teams are created where each student team member has selected their first or second CE area of interest. Each team selects a team member to act as team leader and an assistant team leader. Teams select a CE task leader and assistant task leader for each CE technical area. This process simulates the assignment of a project within an engineering design firm to a team of engineers within the firm by the firm's principles. After the project scope has been defined, each team is tasked with preparing a design work plan, determining design parameters, evaluating design alternatives, design preparation, and materials cost estimating. Initial team activities are devoted to what is referred to as the 'discovery phase' of the project. Teams make team member assignments, develop a work plan, and locate all design references, manuals, standards, aids, and other design literature that may be required but was not initially provided by CE Department faculty members. To assist teams with this and other aspects of the capstone experience, the CE Department utilizes the Mentor concept.

CE Department faculty who are not acting as faculty technical consultants to the student design teams, are assigned as mentors to the teams. Faculty mentors provide non-technical information, direction and motivation to each student design team. They help the teams stay focused and on task. They offer suggestions on time management, team dynamics issues, communications, locating information, and other relevant needs each team may encounter. Teams are encouraged to meet at least weekly with their faculty mentors to review their weekly design activity project journal entries. This activity simulates the project design progress meetings between the design team and the principle engineers at an engineering design firm.

The CE Department's coordination of the capstone experience during each semester is conducted through the department's regularly scheduled faculty meetings as a recurring agenda item. Much of the capstone experience course structure and dynamics is a direct outcome of the discussions during these faculty meetings. Utilizing this continual course assessment method has greatly improved the success of the class with both the students and faculty. An example is a modification that satisfied student concerns about course work load and ABET professional preparation requirements. Beginning with the 2012-2013 academic year, the number of credit hours was increased from two to three providing students more time to work on the design project and more class time for topic presentations and activities to address an ABET program criterion on an ability to explain basic concepts in management, business, public policy, and leadership. 


\section{Course Expectations}

Several assessment tools and mechanisms are used to evaluate the capstone experience in achieving the goals and objectives established for the course. Major concerns include future student success in the CE profession, providing a quality CE education, the ability of graduating students to apply knowledge and skills obtained from CE curriculum courses, and that the capstone experience mirrors 'real world' CE projects.

Rubrics based scoring forms are made available to students and are used by faculty to score assessment tools (Tables 1-4). Students have the option to use peer assessed grading to address negative group dynamic issues.

Assessment tools and mechanisms require students to be involved in the following activities.

1. Group organization, communication, and coordination.

- This activity requires students to experience and apply group dynamics concepts in an engineering design project environment.

- Students use a variety of face to face, mobile, computer, and electronic methods to organize their design teams, as well as communicate and coordinate their project activities.

- Students gain experience assigning and taking responsibility for project duties and functions.

2. Prepare a design project work plan.

- The activity requires students to develop an approach and timeline for identifying and completing project components and work tasks.

- Computer software, such as Microsoft ${ }^{\mathrm{TM}}$ Project ${ }^{\circledR}$, can be used to prepare the project work plan or it can be done manually utilizing the principles of PERT and/or GANT chart development.

- Students gain experience with the importance of time management on CE projects.

3. Maintain an up-to-date project design journal.

- Students learn the importance of maintaining focus on project activities through periodic review of the status of project activities.

- Students gain experience with the importance of time, personnel, and resource management.

- Students coordinate their activities with faculty mentors to simulate meetings with a CE firm's principle or senior project engineers.

4. Determine design parameters, evaluate alternatives, and perform CE calculations that are part of technical design reports.

- Students apply knowledge and skills from their CE curriculum courses to an open ended CE design project.

- Students learn to locate and obtain information, documents, design aids, etc. not provided by faculty, but required to complete the design project.

- Students learn to analyze a CE design challenge to determine a result that satisfies all project constraints. 
5. Write technical CE design reports.

- Student design teams write a Conceptual Project Design report that also includes the team's work plan.

- Student design teams write a Preliminary Project Design report.

- Student design teams write a Final Project Design report.

6. Prepare a basic materials and cost estimate of the final project design.

- Students determine project materials, quantities, and equipment.

- Using published sources, students prepare a basic project cost estimate.

7. Make formal design project presentations.

- Student design teams use presentation software, such as Microsoft ${ }^{\mathrm{TM}}$ PowerPoint ${ }^{\circledR}$, to prepare multimedia materials for project presentation to faculty and clients.

- Student design teams present their preliminary project design to faculty and clients at mid-semester.

- Student design teams make a formal presentation of their final project design to faculty and clients at the end of the semester.

8. ABET CE profession topics.

- Students attend five ABET CE profession topic presentations and write a short reaction paper for each presentation. The topics include; Civil Engineering Design Process, Profession and Licensure, Global Perspective, Business, and Leadership.

- Speakers represent knowledgeable and experienced local area professionals.

\section{Recent Projects}

Titles of some recent projects are listed below to give a flavor of the type of projects we used for the capstone course:

1. "St. Michaels Community Wastewater Treatment System Relocation", St. Michaels, ND (Spring 2013)

2. "Design of civil infrastructure for Shadow Wood development", West Fargo, ND (Fall 2012)

3. "City Park, RV Camping Facilities, and Community Center", located in Harwood, ND. No actual client/owner. (Spring 2012)

4. "Hector Airport International Terminal, Runway Extension, and Taxiways", located in Fargo, ND. Fargo Airport Authority, owner. (Fall 2011)

5. "Agricultural Equipment Museum and Research Center", located in Rollag, MN (Spring 2011).

6. "Southview Condominium Garages, Driveway, and Parking Lot Reconstruction", located in Fargo, ND. Southview Condominium Association, owner. (Fall 2010)

7. "Buffalo River Race Park and Speedway", located in Glyndon, MN. (Spring 2010)

\section{Student Feedback}

Student concerns of the course and the corresponding actions taken to address them are summarized and submitted by the instructor to the department Chair at the end of the course each 
semester. Some weaknesses indicated and the actions taken to improve the course are shown here as examples:

Over a period of years a consistent concern expressed by the students was the course was too demanding in terms of time and effort for two credits. In response, the department decided to increase the credit to three. The idea of extending the course to two semesters is also under consideration.

Another concern was lack of student understanding regarding the concept and procedures of the course. In response, we provided more detailed written and verbal explanation of course and project purpose, requirements, and procedures, applied the use of rubrics for determining scoring criteria, simplified the scoring format and calculations, and added pre- and post-testing relative to professional development assignments. However, pre- and post-testing of student reports on the ABET topics presented in the class was logistically impossible to continue. It was tried in one semester for the Professional Engineering and Tau Beta Pi (TBP) Engineering Futures topics. With the addition of more ABET topics and not having advanced knowledge of presentation content, it became too difficult to continue this form of outcome assessment.

Another student concern was to allow electronic submission. In response, we put the course on BlackBoard so students could access course material any time they want from anywhere with internet access. Students could also submit their reports, journals, and reaction papers via BlackBoard.

Yet another suggestion by the students was to increase the opportunity for faculty interaction time to make sure they are on the right track with respect to the project progress and time management and also to make sure all students in the groups participate without slack. In response, we assigned faculty mentors for each group in addition to their discipline specific consultants

\section{Course Assessment Results}

Three tools are used in the assessment of the course:

- Student reaction papers [for the last two course objectives]

- Mid-semester and final oral presentation [for the last four course objectives]

- Mid-semester and final written report [for all six course objectives]

The performances of students in the capstone course have been very consistent in the past several years. The average score has been in a narrow range of 84 to 89 (out of 100) for both the oral presentations and written reports. Based on the typical criteria used for assessing other civil engineering courses in the curriculum, the score range of 84 to 89 corresponds to a scale of 4 (1 to 5 scale) or a very good level. The performance target for all objectives for all courses in the curriculum is a rating of 80 or a scale of 4 . Therefore, the performance meets the target. However, revisions are being planned to further enhance learning and assessment. The planned revision includes 
- Develop more specific guidelines for various aspects of the engineering components of the course.

- Incorporate a mid-semester evaluation to collect student input relative to the course (and course objectives).

- Find a different approach instead of averaging the scores to assess the performances and attainment levels for course objectives to reflect the distribution of the performances.

- Provide a short refresher training on the use of AutoCAD since there is a big time gap between when the students normally take the CAD course (first semester of sophomore year) and the capstone course (last semester before graduation).

Though no formal assessment of the course objective of emulating real-world project work could be carried out because of the practical difficulty of having practicing professionals evaluate the final design due to their time limitation and work schedule, occasionally we did have practitioners evaluate the presentations. Each semester engineering practitioners involved in the project are invited to make class presentations. They also are invited to participate in evaluating design team presentations. We could not have practitioners evaluate the design reports because of the short turnaround time requirements. Some of the work products (designs) were adopted (with modifications) by project owners. Students had plenty of opportunity to meet with clients (actual sponsors or owners of the project) to talk about the project conceptualization and with practicing professionals about the design processes and alternatives. Most of the comments received during exit interviews related to capstone course are on how open-ended the course is. Students are uncomfortable and struggling with that and prefer a perfectly well defined project. Students somehow have this pre-conception that all project details are clearly defined in the real world. However, at the end of the project students seem to reluctantly accept that real world problems are seldom well defined and almost always are open-ended.

\section{Conclusion}

The capstone experience course continues to be a work in progress as the department responds to student and ABET requests, concerns, and suggestions. The course, in its present form, encompasses those responses deemed to be an improvement to the student's educational experience. During the 2012-2013 academic year, both department faculty and students have voiced a better understanding and acceptance of the course. Based on this positive buy-in, the current capstone course model will be followed during the 2013-2014 academic year. Course outcomes will continue to be monitored with annual departmental review of the model.

\section{References}

[1] Andersen, D. A. (1992). “Civil Engineering Capstone Design Course.” Journal of Professional Issues in Engineering and Education, Vol. 118, No.3.

[2] Padmanabhan, G., Bengtson, M. L. and Andersen, D. A. (1996). "Evolution of a Civil Engineering Capstone Design Course." Proceedings of the 58th Annual American Society for Engineering Education North Midwest Section Meeting, October 3-5, Fargo, North Dakota, pp. I. B-4.1-7.

[3] Padmanabhan, G. and Katti, D. (2002). "Using Community-Based Projects in Civil Engineering Capstone Courses." Journal of Professional Issues in Engineering Education and Practice, 128(1), 12-18. 
Table 1. Rubrics for scoring preliminary (mid-semester) design reports

Department of Civil Engineering North Dakota State University

\author{
CE 489 - SENIOR DESIGN \\ Capstone Experience
}

Fall Semester

Aug. 22 - Dec. 16, 2011

\begin{tabular}{|c|c|c|c|}
\hline \multicolumn{4}{|c|}{ Scoring Checklist for Written Project Reports } \\
\hline \multicolumn{4}{|c|}{ Project Phase: Preliminary Design Report ( $15 \%$ of course grade) } \\
\hline \multicolumn{2}{|l|}{ Evaluator: } & & \\
\hline CRITERION & $\begin{array}{l}\text { Max } \\
\% / \text { pts }\end{array}$ & $\begin{array}{l}\text { Score } \\
\% / \text { pts } \\
\end{array}$ & Comments \\
\hline \multicolumn{3}{|l|}{ Technical Content ( $60 \% / 9$ pts ) } & \\
\hline Design work, tasks, and schedule identified. (5) & $10 / 1.5$ & & \\
\hline Project statement identifies purpose. (5) & $5 / 0.75$ & & \\
\hline Executive Summary clearly summarizes design work. (8) & $5 / 0.75$ & & \\
\hline Analysis \& discussion demonstrates subject mastery. (1) & $30 / 4.5$ & & \\
\hline $\begin{array}{l}\text { Design alternatives and conclusions appropriate and } \\
\text { complete. (3) }\end{array}$ & $10 / 1.5$ & & \\
\hline \multicolumn{3}{|l|}{ Organization ( $10 \% / 1.5$ pts ) } & \\
\hline $\begin{array}{l}\text { Required report components distinctly identified and } \\
\text { cohesive. }(4,7,8)\end{array}$ & $5 / 0.75$ & & \\
\hline $\begin{array}{l}\text { Content clearly and logically organized and good } \\
\text { transitions. (8) }\end{array}$ & $5 / 0.75$ & & \\
\hline \multicolumn{3}{|l|}{ Presentation ( $10 \% / 1.5$ pts ) } & \\
\hline Spelling, grammar, and syntax. Clear \& easy to read. (8) & $5 / 0.75$ & & \\
\hline $\begin{array}{l}\text { Good use of tables, figures, graphs, charts, references, } \\
\text { etc. }(2,8,12)\end{array}$ & $5 / 0.75$ & & \\
\hline \multicolumn{3}{|l|}{ Quality of Drawings and Graphics ( $20 \% / 3$ pts ) } & \\
\hline Site plan, design drawings, maps, pictures, etc. (8) & $20 / 3$ & & \\
\hline TOTAL SCORE ( $\% /$ pts) & $100 / 15$ & & \\
\hline
\end{tabular}

NOTE: The number(s) after each criterion is (are) course objective number(s) listed in the course syllabus that, in turn, relate to ABET accreditation criteria.

[Form Date: $8 / 23 / 2011$ ] 
Table 2. Rubrics for scoring final design reports

Department of Civil Engineering North Dakota State University
CE 489 - SENIOR DESIGN

Capstone Experience
Fall Semester

Aug. 22 - Dec. 16, 2011

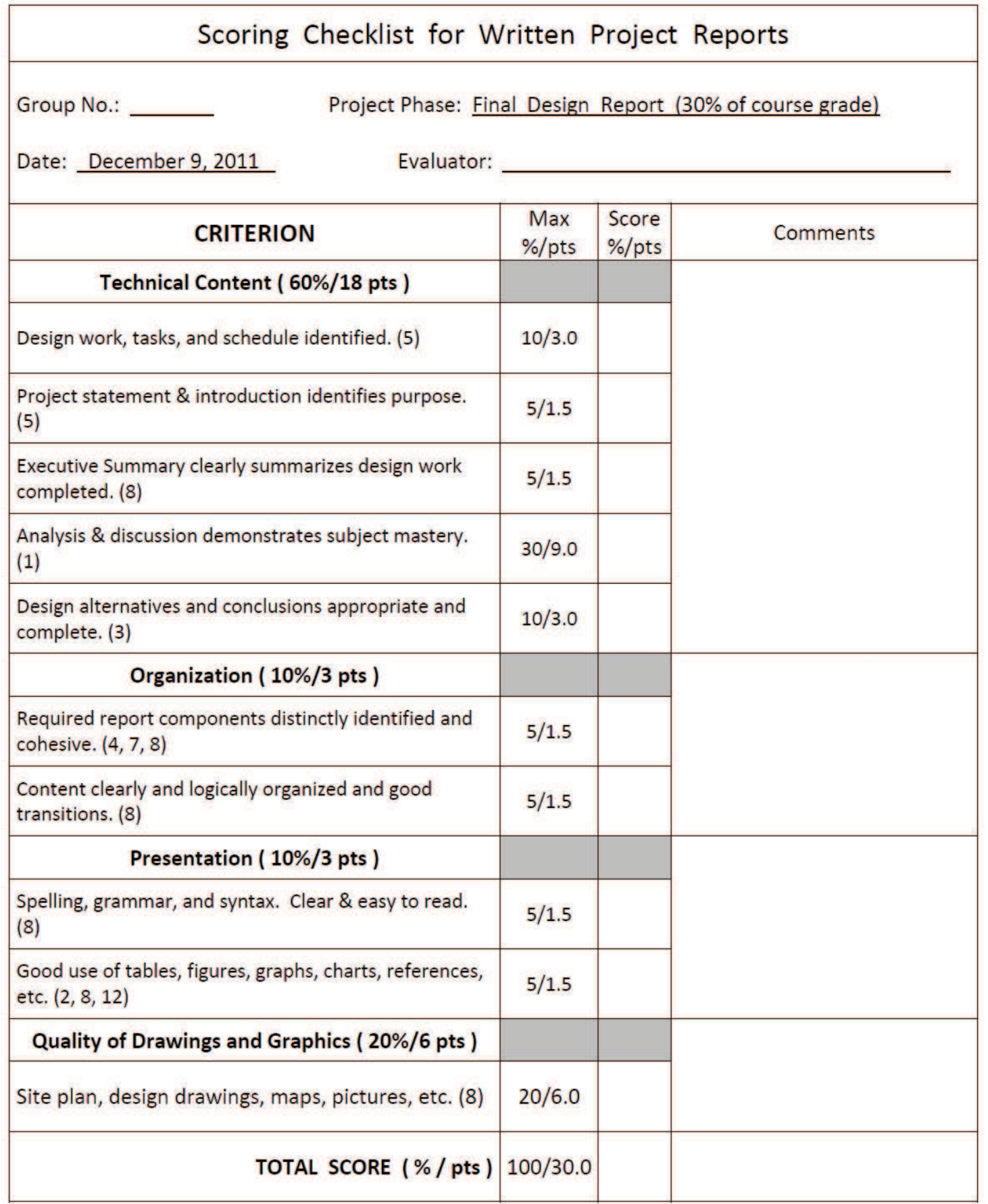

NOTE: The number(s) after each criterion is (are) course objective number(s) listed in the course syllabus that, in turn, relate to ABET accreditation criteria.

[Form Date: $8 / 23 / 2011$ ] 
Table 3. Rubrics for scoring preliminary (mid-semester) design presentations

Civil Engineering Department North Dakota State University
CE 489 - SENIOR DESIGN Capstone Experience
Fall Semester Aug. 22 - Dec. 16, 2011

\begin{tabular}{|c|c|c|c|}
\hline \multicolumn{4}{|c|}{ Scoring Checklist for Preliminary Design Presentations } \\
\hline \multicolumn{4}{|c|}{ Group No.:____ Project Phase: Preliminary Design Group Presentation ( $10 \%$ of course grade) } \\
\hline Date: October 11 \& 13, 2011 & \multicolumn{3}{|c|}{ Evaluator: } \\
\hline CRITERION & \begin{tabular}{c|c} 
Max \\
$\% / p t s$
\end{tabular} & \begin{tabular}{|l|} 
Score \\
$\% /$ pts \\
\end{tabular} & Comments \\
\hline \multicolumn{4}{|l|}{ Technical Content ( $60 \% / 6.0 \mathrm{pts}$ ) } \\
\hline Environmental Task Area $(1,2,3,5)$ & $12 / 1.2$ & & \\
\hline Geotechnical Task Area $(1,2,3,5)$ & $12 / 1.2$ & & \\
\hline Structural Task Area $(1,2,3,5)$ & $12 / 1.2$ & & \\
\hline Transportation Task Area $(1,2,3,5)$ & $12 / 1.2$ & & \\
\hline Water Resources Task Area $(1,2,3,5)$ & $12 / 1.2$ & & \\
\hline \multicolumn{4}{|l|}{ Organization ( $15 \% / 1.5$ pts ) } \\
\hline $\begin{array}{l}\text { Design components distinctly identified \& cohesive and } \\
\text { design content clearly \& logically organized \& good } \\
\text { transitions. }(4,7,8)\end{array}$ & $15 / 1.5$ & & \\
\hline \multicolumn{4}{|l|}{ Presentation ( $15 \% / 1.5 \mathrm{pts}$ ) } \\
\hline Introduction of the Group Members \& the Project ( 7 ) & $5 / 0.5$ & & \\
\hline Participation by All Group Members ( 4 ) & $5 / 0.5$ & & \\
\hline Response to Questions $(4,7)$ & $5 / 0.5$ & & \\
\hline \multicolumn{4}{|l|}{$\begin{array}{c}\text { Quality of Slides, Overheads, Graphics, etc. } \\
\text { (10\%/1.0 pts) }\end{array}$} \\
\hline Use of Visual Aids ( 8 ) & $10 / 1.0$ & & \\
\hline TOTAL SCORE & $100 / 10$ & & \\
\hline
\end{tabular}


Table 4. Rubrics for scoring final design presentations

Civil Engineering Department North Dakota State University
CE 489 -SENIOR DESIGN Capstone Experience
Fall Semester Aug. 22 - Dec. 16, 2011

\begin{tabular}{|c|c|c|c|}
\hline \multicolumn{4}{|c|}{ Scoring Checklist for Final Design Presentations } \\
\hline \multicolumn{4}{|c|}{ Project Phase: Final Design Group Presentation (10\% of course grade) } \\
\hline Dates: December 6 \& 8, 2011 & \multicolumn{3}{|c|}{ Evaluator: } \\
\hline CRITERION & $\begin{array}{c}\text { Max } \\
\% / \text { pts }\end{array}$ & $\begin{array}{l}\text { Score } \\
\% / p t s\end{array}$ & Comments \\
\hline \multicolumn{3}{|l|}{ Technical Content ( $60 \% / 6.0$ pts) } & \\
\hline Environmental Task Area $(1,2,3,5)$ & \multicolumn{2}{|l|}{$12 / 1.2$} & \\
\hline Geotechnical Task Area $(1,2,3,5)$ & \multicolumn{2}{|l|}{$12 / 1.2$} & \\
\hline Structural Task Area $(1,2,3,5)$ & \multicolumn{2}{|l|}{$12 / 1.2$} & \\
\hline Transportation Task Area $(1,2,3,5)$ & \multicolumn{2}{|l|}{$12 / 1.2$} & \\
\hline Water Resources Task Area $(1,2,3,5)$ & $12 / 1.2$ & & \\
\hline \multicolumn{3}{|l|}{ Organization ( $15 \% / 1.5$ pts ) } & \\
\hline $\begin{array}{l}\text { Design components distinctly identified \& cohesive and } \\
\text { design content clearly \& logically organized \& good } \\
\text { transitions. }(4,7,8)\end{array}$ & $15 / 1.5$ & & \\
\hline \multicolumn{3}{|l|}{ Presentation ( $15 \% / 1.5$ pts ) } & \\
\hline Introduction of the Group Members \& the Project ( 7) & $5 / 0.5$ & & \\
\hline Participation by All Group Members (4) & $5 / 0.5$ & & \\
\hline Response to Questions $(4,7)$ & $5 / 0.5$ & & \\
\hline \multicolumn{3}{|l|}{$\begin{array}{l}\text { Quality of Slides, Overheads, Graphics, etc. } \\
\qquad(10 \% / 1.0 \mathrm{pts})\end{array}$} & \\
\hline Use of Visual Aids ( 8 ) & $10 / 1.0$ & & \\
\hline TOTAL SCORE & $100 / 10$ & & \\
\hline
\end{tabular}

NOTE: The number(s) after each criterion is (are) course objective number(s) listed in the course syllabus that, in turn, relate to $A B E T$ accreditation criteria.

[Form Date: 8/23/2011] 